\title{
THE IMPACT OF RELATIONSHIP MARKETING WITH CUSTOMERS ON THE FINANCIAL PERFORMANCE OF THE SUNFLOWER OIL MANUFACTURERS IN SERBIA
}

\author{
Danijela Andjelković', Milan Vujić², Ana Liberakos ${ }^{3}$, Danijela Zubac $^{4}$
}

\begin{abstract}
Summary
The purpose of this study is to investigate empirically how determinant attributes of price and brand, based on relationship marketing concept, influence customerperceived value as well as long-term profit in the Serbian sunflower oil industry.

For the purpose of this study, a self-administrated questionnaire was distributed to 125 respondents. This questionnaire has been created to collect primary data and it has a structure that reflects statements which show customers' satisfaction determinant attributes. A descriptive and multiple regression analysis was used to identify which factors of determinant attributes of customers'satisfaction influenced customer-perceived value. Therefore, we perceive the influence of satisfaction and its attributes as nonfinancial measures on financial measures which are related to enterprise performance. This study found that factors of determinant attributes of price and brand significantly and statistically influenced the satisfaction, whereas the manufacturer's brand has the greatest influence. Furthermore, analyzing the loyalty of customers as a second key factor of relationship marketing, the results of this study undoubtedly confirmed that only the brand significantly influenced customers' loyalty. The price represents a significant factor in providing immediate customers'satisfaction. But, in the long run, the focus of customers is on those oil manufacturers who have a powerful brand (corporate reputation). The study opens possibilities of discussion in the existing literature due to the fact that it reveals how determinant attributes of customers' satisfaction and loyalty influences the creation of superior value for the customer as well as the creation
\end{abstract}

1 Danijela Andjelković, Ph.D., Assistant Professor, University Union „Nikola Tesla“ , Belgrade, Faculty for entrepreneurial business and property management, Cara Dušana Street no. 62-64, 11080 Belgrade, Serbia, Phone: +381 6422215 61, E-mail: andjelkodani@gmail.com

2 Milan Vujić, M.A., Assistant, High Technology School of Vocational Studies - Arandjelovac, Serbia, Phone: +381 6984490 03, E-mail: kikiv91@gmail.com

3 Ana Liberakos, Assistant, University Union „Nikola Tesla“, Belgrade, Street no. 62-64, 11080 Belgrade, Serbia, Business and Law Faculty, Beograd, Mladenovac, Ontario, N2T 1W3, Canada, E-mail: ana.liberakos@gmail.com

4 Danijela Zubac, Phd., Professor of Vocational Studies, Higher Technical Professional School, Zvečan, E-mail: danijela.marjanovic@gmail.com

EP 2018 (65) 1 (93-109) 
of long-term value for the enterprise. This study found that the process of creation enterprise's value was not based on a traditional formula, where it began with input and ended with the output. The mere input for the creation of enterprise's output emerges from interaction with customers. In this context, it's very important to take into account the economic effect between the consistent creation of superior value for the customer and long-term profit. Moreover, the importance of this study emerges from research results which show that modern market conditions impose the need for tailoring financial statements that are based on various interest groups. In this way, additional non-financial measures of success are provided as well as information in relation to those that can be obtained from existing basic financial statements.

Keywords: sunflower oil, price, brand, relationship marketing, satisfaction, financial performances.

JEL: M31, Q14, C81

\section{Introduction}

Managing relationship marketing in relation to customers represents one of the most important the twenty-first century management processes. It is aimed at obtaining a value for the customer (Gummesson, 2008; Kotler, 2000). The implications of this relationship have an impact on edible oils manufacturers' financial performances. Therefore, the value of a relationship with customer ought to be analyzed in the same manner as the value of business enterprise (value chain) (Lukić and Nikolić, 2009). In the context of global competition, a customer is offered a product or service that have a superior value and which is believed to represent the best way for gaining a competitive advantage (Woodruff, 1997). This approach to marketing strategy in creating superior value for a customer is of utmost importance for sunflower oil manufacturers in Serbia. This value should provide them with economic growth and development.

Besides forecasting the sales volume of one product, it is of vital importance to forecast the profit from customers as well in order to carry out strategic management of one enterprise. Taking into account the profit as a criterion for segmentation, Marinkovic (2012) argued that for the purpose of identifying strategically important customer categories one can implement various analysis methods and indicators such as RFM method, marketing ROI analysis, CLV (customer lifetime value). Customer lifetime value encompasses total financial contribution of customers, i.e. it includes future income expectations and costs, the rate of customer retention as well as a discount rate (Kumar, 2006a). In addition to Kumar's definition, Gupta and Lehmann (2006) define CLV as a value which encompasses all existing and future profits gained from customers throughout their relationship (cooperation) with the enterprise. In this context, the aim of research in this study is focused on applying various procedures, techniques and methods for measuring customers' performances in order to emphasize the sunflower oil manufacturers' necessity and feedback for developing close and lifelong (long-term) relationship with customers. By doing so, the manufacturers will be capable of getting 
customers' loyalty which will also enhance their satisfaction. Therefore, all abovementioned techniques and methods ought to contribute to higher enterprise value that will lead to the increase of its profitability too. According to value chain concept, some elements that are related to customers' satisfaction, loyalty, retention, and profitability represent important guidelines in view of relationship marketing with customers (Gupta and Lehmann, 2006a). Moreover, by applying Balanced Scorecard methodology (Kaplan and Norton, 1992; Wu et al., 2009) the contribution of non-financial measures to financial measures of Serbian sunflower oil manufacturers' performances is clearly and explicitly determined. The methodological aim of this research tries to determine customers' attitude to crucial elements of customers' satisfaction and loyalty that are related to brand and price of sunflower oil manufacturers' products. According to the goal set, the following hypotheses are set out in this paper:

H1. Prices are an important factor in providing immediate customers' satisfaction and loyalty. On the other hand, in the long run, product brand i.e. sunflower oil manufacturers' reputation represents a crucial impetus (trigger) for creating superior value for a customer as well as a long-term profit.

H2. Input for creation the sunflower oil manufactures' output emerges from customers i.e. interaction with customers.

For the purpose of supporting (proving) these hypotheses, the research results of this study are presented by applying descriptive statistics and multiple regression analysis. In the introductory section of this study, the relationship between marketing and financial dimensions are explained as well as customers' satisfaction and loyalty implications that have an impact on financial performances of an enterprise.

\section{Relationship between marketing and financial dimension}

Kaplan and Norton developed "balanced scorecard" concept which was originally presented in Harvard Business Review in 1992. Later on, this concept was thoroughly developed in their books (Kaplan and Norton, 1996, 2003, 2004). Looking at aims from different perspectives, the adjusted list (Djuričin et al., 2010) creates the balance between general indicators (financial consequences of previous decisions) and starting indicators (the measures of future indicators which show ways of creating value by investing in customers, suppliers, employees, technology, innovations and other forms of nonmaterial assets). Nowadays, managing the enterprise that is based on its long-term goals and visions is feasible only if parameters that are used for it, contain indicators which reflect not only the past but also information about future development. Kaplan and Norton's Balanced Scorecard instrument doesn't take into consideration only financial, but also non-financial indicators as well. Furthermore, they divided parameters into four different perspectives (dimensions): financial perspective, customer perspective, internal processes perspective, learning, and development perspective (Domanović, 2010).The parameter of financial perspective that is used for achieving the aims of enterprise, is also important because we can derive from it other three perspectives. The 
indicators that contribute to the successful processing of market and customers (e.g. customers' satisfaction) are developed within customer perspective. When we take into account the creation of an appropriate strategy for enterprise management, it is vital to use an integrated approach to marketing and financial dimension.

Modern businessconditions, interactiverelationship between participants at a competitive market, as well as the mere struggle for survival at the market, require making numerous strategic decisions on a daily basis. Therefore, in the context of economic integrity, information from financial statements (in the span of few years) is the basis for analysis of the economic and financial behavior of an enterprise that also represents a necessary element for making business decisions (Ivkov, 2014). Providing the quality system of informing by the help of financial indicators involves also the existence of complete, precise, comparative and accessible information (Ivkov and Andjelković, 2013). The processing of such information is also the basis for marketing information, as well as for the creation of the enterprise future growth. The innovative marketing strategy that is best defined, could also fail unless it is followed by appropriate financial strategy. On the other hand, the financial strategy that is aimed at the realization of high-profit rate can't be completed (realized) unless it is followed by appropriate marketing strategy for the realisation of planned sales volume. Financial strategy of an enterprise is aimed at a successful combination of sales volume, costs, expenses, profit, asset, debts, and investments in order to reach the specific liquidity and profitability level. The given goals (objectives) are put in an appropriate financial program in order to be realized. Financial programme depends on marketing programme. This relationship is evident in all elements of the financial programme, especially in elements such as sales volume, costs, and investments. By combining analytically financial aims and programme we can obtain various models of profitability. Given models are used for evaluating financial implications of enterprise marketing strategies. Profitability models play a crucial role in the overall process of strategic management. These models are important for combining three key areas of enterprise management: 1) profit management; 2) business assets management; 3 ) capital management (sources of capital and debt ratio). There is a high level of the interrelationship among these areas. Furthermore, these three areas are often reduced to two strategic ones. The first area is associated with assets and capital management- financial strategy, whereas the second one is associated with profit management- marketing strategy (Lovreta, 1998). Customer profitability management (CPM) brings an effective cost and price management so as to create programmes for profit increase. A continuous monitoring of changes in profitability of different segments means that enterprise adjusts to changes and becomes an active creator of new trends in today's market. CPM in combination with effective material and non-material assets makes it feasible for the enterprise to identify the chances for value creation in order to increase customer profitability. However, in the long run, enterprises that don't upgrade and differentiate its products become incapable of keeping profitable customer segments (Wang, Hong, 2006). That way, an act of measuring customer profitability adds an additional and new dimension to marketing 
which leads to an establishment of the relationship between marketing and finances in terms of increasing enterprise value. There have been significant changes in marketing concept due to the fact that implementation of financial calculations in marketing has been used to assess customer profitability and brand value (equity). The concept of CLV implies the necessity of integration for marketing and financial activities. Moreover, CLV represents the link that connects these two traditional business functions. With the expansion of CLV concept, it is feasible to determine the impact of marketing strategies on enterprise value more precisely (Gupta and Lehmann, 2006b; Askary, 2013; Kumar, 2006b; Hughes, 2006). It is evident that an integral approach to financial and nonfinancial determinants is necessary during the creation of an appropriate enterprise management strategy which will lead to its growth and development.

\section{Implications of customer satisfaction on financial performances}

A group of professors from Harvard, Hesket, et al., (2003) has developed a concept "The value profit chain", which implies that the value can be assessed from the customer's point of view as well as from employees, investors, and partners of one enterprise. Moreover, this concept offers patterns for calculating the value for above-mentioned stakeholders. Satisfaction and customer loyalty represent the primary growth factors of the profitability of the enterprise that imply the value for investors and partners. In marketing, satisfaction is associated with the feeling that occurs in the evaluation stage after purchasing and consuming products and using services. Costumers feel satisfied if a product or service meets or exceeds their expectations. That is why "creating a value and customer satisfaction are at the heart of modern marketing thought and practice. Customer satisfaction is the key to retaining existing and attracting new customers (Maricic, 2011). Satisfaction is generally analyzed as a function of the performance of the purchased product and previous expectations. "Satisfaction is a customer's response to achievements. This represents the price that shows attributes of a product or service, or just a product or service which provide a pleasant level of consumption, including those levels of insufficient or excessive fulfillment". This approach to the definition has led to the formation of a new model whose significance is reflected in the fact that it represents one of the first attempts to test the correlation relationship between satisfaction and affection. In this context, the model is the basis for future researchers (Oliver, et al., 1997). The concept of customer satisfaction is the subject of special attention in marketing because it is reasonably believed that satisfaction affects the intentions and future behavior of the customer. Szwarc, (2005), has yielded significant results in customer satisfaction studies. The created customer satisfaction should not be viewed as the goal of overall marketing activity but as a very important step towards the creation of loyal customers. Satisfaction and loyalty of the customers are two key links in the profit-making chain. Auh and Dzonson (2005) emphasize two factors that significantly affect the degree of positive correlation between satisfaction and loyalty. These two factors represent the relative significance of the quality and price of the product itself and they are associated with purchasing and the difficulty in detecting differences in the attributes of brand rivalries of a given product category. A positive 
correlation between satisfaction and loyalty becomes stronger if quality plays a key role in the purchasing process and if consumers are able to easily detect differences in the quality of the attributes of competitive products. If an enterprise creates a sufficient number of satisfied and loyal customers, it will meet the basic prerequisite for achieving long-term profitability. A high level of customer satisfaction in the current period contributes to increasing profits in the enterprise. On the other hand, since the primary goal (objective) of an enterprise lies in a long-term, and not a shortterm profitability, it is necessary to create satisfied loyal customers. An increase in the level of customer satisfaction, as a rule, increases the level of their loyalty. Therefore, customer satisfaction represents an extraordinary market benchmark and a barometer of future revenue and profit. Customer satisfaction is a business-oriented indicator of the future. Other benchmarks, such as sales and market share, are backward-looking benchmarks in business performance measurement. They show what was in the past, without taking into the account the future. Thus, customer satisfaction has become the leading performance indicator for future. The company can have good financial indicators and poor satisfaction, due to the fact that customers are not capable of changing the source of supply in a short period of time. Customers who are unsatisfied, usually do not regret the company's abandonment. In order to maintain market share, new customers have to be attracted (Milisavljević, 2006).

According to Sheth, et al., (1999), the customer-orientated approach provides enterprises with specific benefits that result in increased profitability and revenue growth. In this regard, six advantages are listed, of which three affect the increase in profitability, and other three the increase in the revenue of the enterprise. Specific benefits that affect the increase in profits are 1) cost-effectiveness (reduction) through repeated purchases; 2) preferential prices for regular customers, 3) The loyalty of customers during the periods of crisis for an enterprise. The specific benefits that affect the growth of revenue are: 1) the positive effect of oral propaganda, 2) the increase in the number of trial purchases, and 3) the innovation of new products. By maximizing customer satisfaction, an enterprise maximizes profitability and its market share. An enterprise can always increase the level of customer satisfaction by lowering prices or improving the quality of services. However, this can frequently result in a decline in profits, and this is certainly the leastdesirable business option. Therefore, the purpose of enterprise orientation to achieve a higher level of customer satisfaction is to offer them greater value in products and services at an adequate price, which is also profitable for an enterprise. It is known that quality products and services correspond to higher prices for the offer. Customers will also accept higher prices with increased value in products and services, which will also affect the increase in corporate profits. Creating value for customers and the degree of their satisfaction are key elements in developing and managing relationship marketing with customers. Such an approach has led to an explicit measurement of the impact of the company's bid on creating value for customers. Payne and Holt, (2001), made a significant contribution to measurements in order to understand customers' value and degree of their satisfaction. In a study undertaken by Ladhary et al., (2008), the quality 
of interaction surfaced as important triggers of satisfaction. The research results confirm that there is a high level of influence of product or service quality on the increase in customer satisfaction (Brady and Robertson, 2001; Yang et al., 2009). Likewise, the research confirms that the price has a significant impact on customer satisfaction and loyalty (Bei and Chiao, 2001). Measuring customer satisfaction is a very significant business activity of a market-oriented enterprise. The results obtained provide useful guidelines for improving existing relationships with customers. The information provided in this way serves as an important step for sunflower oil manufacturers in order to determine the contribution that their activities aimed at increasing customer satisfaction have so as to improve the value creation process for the customer as well as to increase the value itself. All studies and other relevant papers presented here are used in this study in order to investigate a complex system of evaluating key determinants and business indicators for the purpose of evaluating the possibility of further growth and development of the oil industry, and thus the overall economy.

\section{Methodology}

Measurement of customer satisfaction as a key element of relationship marketing is based on a process that was used by renowned authors in this field, Churchill, and Iacobucci, (2002). In this context, the following stages of the process of measuring customer satisfaction were applied in this paper: 1) defining the problem;2) designing the research; 3) determining methods and techniques for collecting data; 4) sampling and collecting data; 5) analysis and interpretation of data. The usage of Balanced Scorecard model is significant for the oil industry from the perspective of customers. In accordance with the premise of research in this paper, field surveys were carried out, according to the set goals and performance criteria (Table 1.) for the purpose of identifying statistically significant determinants of customer satisfaction and loyalty.

Table 1. Objectives, performance benchmarks, initiatives

\begin{tabular}{|l|l|l|}
\hline Objectives & Performance benchmarks & Initiatives \\
\hline $\begin{array}{l}\text { Create a strong relationship with } \\
\text { customers }\end{array}$ & Customer satisfaction & $\begin{array}{l}\text { Develop a customer feedback } \\
\text { database }\end{array}$ \\
\hline
\end{tabular}

Source: own review

The intention is to prove that the value for the customer is created within the two-way interactive process of the sunflower oil producer and the purchaser. This perspective of value creation is based on the idea of mutual knowledge exchange, which automatically leads to the creation of higher values for both sides. Customer satisfaction surveys are conducted according to price and brand in the retail sector in the territory of the City of Belgrade and Novi Sad. These surveys are based on the determination of the size and structure of the sample. The sample was created on a case-by-case basis in locations in central city zones. The reason for this lies in the fact that there is a significant concentration of respondents in the mentioned zones and an organized trade supply service. However, there are also respondents in areas where there is no significant concentrated and organized supply of sunflower oil. The research was based on a 
sample size of $\mathrm{n}=125$ subjects. Also, the sample includes the defined age structure and schooling (education) of respondents. When it comes to the gender structure, the sample includes 69 women (55. 2\%) and 56 males (44. 8\%). The main goal of the research was to determine the relationship between purchasers, citizens of Belgrade and Novi Sad, according to the key elements of satisfaction related, the price of the products of the oil industry, and the brand of sunflower oil producer and their reputation. In this context, the research was carried out to identify statistically significant determinants of customer satisfaction and loyalty. Survey of satisfaction and loyalty of purchasers was carried out according to the attached questionnaire (Table 2.).

Table 2. Questionnaire on customer satisfaction with the price and brand of sunflower oil producers

\begin{tabular}{|c|c|c|c|c|c|c|c|c|}
\hline \multirow{2}{*}{ No. } & \multirow{2}{*}{$\begin{array}{l}\text { Statements (Claims) } \\
\text { The prices of sunflower oil products are more } \\
\text { favorable than what you expected }\end{array}$} & \multicolumn{4}{|c|}{ 1-absolutely disagree } & \multicolumn{3}{|c|}{ 7-absolutely agree } \\
\hline & & 1 & 2 & 3 & 4 & 5 & 6 & 7 \\
\hline 2 & $\begin{array}{l}\text { Prices of sunflower oil are correct compared to } \\
\text { other types of oil of foreign competition }\end{array}$ & 1 & 2 & 3 & 4 & 5 & 6 & 7 \\
\hline 3 & $\begin{array}{l}\text { Prices of sunflower oil products are in accordance } \\
\text { with the quality they offer }\end{array}$ & 1 & 2 & 3 & 4 & 5 & 6 & 7 \\
\hline 4 & $\begin{array}{l}\text { The oil producer chain relates to reputable and } \\
\text { professional enterprises of the oil industry in } \\
\text { Serbia }\end{array}$ & 1 & 2 & 3 & 4 & 5 & 6 & 7 \\
\hline 5 & $\begin{array}{l}\text { On the whole, the image of a sunflower oil } \\
\text { producer is favorable }\end{array}$ & 1 & 2 & 3 & 4 & 5 & 6 & 7 \\
\hline 6 & $\begin{array}{l}\text { The products of sunflower oil producers are } \\
\text { directed towards the needs and wishes of the } \\
\text { customers }\end{array}$ & 1 & 2 & 3 & 4 & 5 & 6 & 7 \\
\hline 7 & $\begin{array}{l}\text { Looking back at the overall range of sunflower } \\
\text { oil producers, you are very satisfied }\end{array}$ & 1 & 2 & 3 & 4 & 5 & 6 & 7 \\
\hline 8 & $\begin{array}{l}\text { The overall offer of sunflower oil producers } \\
\text { greatly exceeds your expectations }\end{array}$ & 1 & 2 & 3 & 4 & 5 & 6 & 7 \\
\hline 9 & $\begin{array}{l}\text { In the future, you intend to continue using the } \\
\text { range of products of the Serbian oil industry }\end{array}$ & 1 & 2 & 3 & 4 & 5 & 6 & 7 \\
\hline
\end{tabular}

Source: own review

The questionnaire that was used to collect data from the respondents covered a total of 9 claims that were evaluated on Likert's seven-point scale, 1 absolutely disagree; 7 absolutely agree (Andjelković, 2014). Claims are grouped around 4 variables. These variables are Prices, Corporate Reputation (Sunflower Oil Manufacturer Brand), Satisfaction and Loyalty. Each variable was measured according to a certain number of statements-claims (two to three statements). The variables represent the unadorned midpoint of the assessments given by the respondents to the findings by which the variables were measured. In this context, prices were measured through the statements 1, 2 and 3. The sunflower oil producer's brand was measured through the statements 4, 5 and 6. Satisfaction of customers was measured through the statements of 7 and 8. Customer loyalty was measured through the statement 9 . The selection of the 
statements by which the attributes of the sunflower oil brand producers were measured was adopted and adapted from Jeng, (2011); The selection of the statements by which prices and satisfaction were measured were made by studies conducted by Johnson et. al., (2001); Iglesias and Guillen, (2004); Cronin, et al., (2000); Fornell et al., (1996). In order to measure loyalty, a statement was taken and adapted from Gaur et al. (2001). Data analysis was conducted in the Statistical Package for Social Sciences version 12. To test the reliability and internal consistency of the statements, on the basis of the aforementioned software program, Cronbach's alpha coefficient for each individual variable was used. To examine the statistical significance of the effects of independent variables on the dependent variable (customer satisfaction), a multiple regression analysis was used.

\section{Results and discussion}

Descriptive sample information suggests that the percentage of women is bigger $(55.2 \%)$ compared to men $(44.8 \%)$. The relative relationship of the mentioned segmentation criteria is harmonized with the final markings or the purpose of the final product. In line with the segmentation of the sample, in the first part of the results of descriptive statistical analysis, we determined the estimates of the statements and attitudes of women and men about the attributes on the basis of which they were segregated as well as measured variables of the model related to the product price, brand, satisfaction and customer loyalty. The results of descriptive statistical analysis based on the data obtained from the survey are illustrated in the tables (Tables 3 and 4.).

Table 3. The results of descriptive statistical analysis (the grades of statements)

\begin{tabular}{|l|l|}
\hline Statements & Grade \\
\hline Prices of sunflower oil products are more favorable than you expected & 3.11 \\
\hline Prices of sunflower oil are correct compared to other types of oil of foreign competition & 3.71 \\
\hline Prices of sunflower oil products are in accordance with the quality they offer & 4.01 \\
\hline $\begin{array}{l}\text { The oil producer chain relates to reputable and professional enterprises of the oil industry } \\
\text { in Serbia }\end{array}$ & 4.58 \\
\hline On the whole, the image of a sunflower oil producer is favorable & 4.49 \\
\hline $\begin{array}{l}\text { The products of sunflower oil producers are directed towards the needs and wishes of the } \\
\text { customers }\end{array}$ & 4.45 \\
\hline Looking back at the overall range of sunflower oil producers, you are very satisfied & 4.26 \\
\hline The overall offer of sunflower oil producers greatly exceeds your expectations & 4.13 \\
\hline In the future, you intend to continue using the range of products of the Serbian oil industry & 4.45 \\
\hline
\end{tabular}

Source: own calculation based on survey database

Based on the results of the statistical analysis, in Table 3, estimates for 9 statements were given. Based on the use of the seven-point Likert scale, the higher estimates of the statements presented in the above table show more favorable attitudes of the respondents. On the basis of the above-mentioned statement, the highest respondents' estimate is that the chain of oil producers refers to renowned and professional enterprises of the oil industry in Serbia (4. 58), and then it follows that the overall view is that the image 
of the oil industry is favorable (4. 49). Likewise, the significant value of the grade also relates to the statement that the products of sunflower oil products are directed towards the needs and wishes of customers (4. 45).

Table 4. The results of descriptive statistical analysis (the grades of model variables)

\begin{tabular}{|l|l|}
\hline Variables & Grade \\
\hline Price & 3.61 \\
\hline Sunflower oil producers' brand & 4.51 \\
\hline Satisfaction & 4.19 \\
\hline Loyalty & 4.45 \\
\hline
\end{tabular}

Source: own calculation based on survey database

In Table 4, based on the analysis results, estimates for model variables are given, since each variable is measured with two, or three statements. The results show that respondents have the most favorable attitude according to the conclusions concerning the brand of the oil industry (4.51), and the most unfavorable attitudes about the statements through which the prices were measured (3.61). Results show that respondents exhibit a higher level of loyalty compared to the level of their satisfaction. To test the reliability and internal consistency of the statements, the aforementioned software program is used for calculating Cronbach's alpha coefficient for each individual variable. Calculated values of Cronbach's alpha are given in the table (Table 5.).

Table 5. The value of Cronbach's alpha coefficient

\begin{tabular}{|l|l|}
\hline Variables & Cronbach's alpha \\
\hline Price & 0.725 \\
\hline Sunflower oil producers' brand & 0.801 \\
\hline Satisfaction & 0.716 \\
\hline Loyalty & 0.762 \\
\hline
\end{tabular}

Source: own calculation based on survey database

Coefficient Cronbach's alpha shows the reliability and internal consistency of the statements through which the model variables are measured. Its value moves in the $0-1$ interval and it is considered that the statements are internally consistent if the value of this coefficient is greater than 0.7 . Taking into account all variables, we have reliable results, i.e. the values of the Cronbach's alpha coefficient for all variables are more than 0.7 . The results from Table 5 show that the highest degree of reliability can be found in the variable of the brand of the products of the oil industry (Cronbach's alpha $=0$. 801 ) as well as in loyalty variable (Cronbach's alpha $=0.762$ ). The results of a multiple regression analysis on the basis of the causal relationship between the dependent and independent variables are shown in the following table (Table 6.). In the observed case of empirical analysis, the influence of two independent variables (price and brand of sunflower oil producer) on the satisfaction as a dependent variable is shown. 
Table 6. The results of multiple regression analysis (dependent variable: satisfaction)

\begin{tabular}{|l|l|l|}
\hline Variables & $\beta$ & VIF \\
\hline Prices & $0.239^{*}$ & 2.013 \\
\hline Oil producers' brand & $0.427 * *$ & 3.121 \\
\hline
\end{tabular}

Source: own calculation based on survey database. Results important at level $\mathrm{p}<0.01$ (**): $\mathrm{p}<0.05(*): \mathrm{R}^{2}=0.605$

From the shown results of a multiple regression analysis, it is evident that both observed independent variables (producer price and brand) have a statistically significant effect on satisfaction, with the strongest impact being the brand name of the sunflower oil producer, since it has the highest value of coefficient $\beta$. Since the Variance Inflation Factor (VIF) is less than 5, it can be concluded that multicollinearity is not a problem in the given research (Andjelković, 2001). The results of a multiple regression analysis in which the dependent loyalty variable represents the function of the two observed independent variables are shown in the following table (Table 7.). In other words, the table below illustrates the impact of two independent variables (price, the brand of the products of the oil industry) on customer loyalty.

Table 7. The results of multiple regression analysis (dependent variable: loyalty)

\begin{tabular}{|l|l|l|}
\hline Variables & $\boldsymbol{\beta}$ & VIF \\
\hline Prices & 0.120 & 2.013 \\
\hline Oil producers' brand & $0.420^{* *}$ & 3.121 \\
\hline
\end{tabular}

Source: own calculation based on survey database. Results important at level $\mathrm{p}<0.01$ (**): $\mathrm{R}^{2}=0.712$

Based on the results of the analysis shown in the table, it follows that the regression model describes $71.2 \%$ variability of loyalty. In the observed case, the results confirm that only the brand of sunflower oil producer has a statistically significant and very strong impact on customer loyalty. In this context, the product brand of a given manufacturer is a key driver in creating long-term customer loyalty. The quality of services and prices are important factors in securing current customer satisfaction, but in the long run, customers are primarily focused on those supply chains of sunflower oil products that have a strong brand, or corporate reputation. Due to the fact that the values of VIF are less than 5 , it can be concluded that multipolarity does not pose a problem in the given research.

\section{Conclusions and implications}

According to the results of the multiple regression analysis, it can be concluded that both observed variables (the price and the brand of the producer) have a statistically significant effect on satisfaction, with the strongest impact being the brand or reputation of the producer of sunflower oil. Another conclusion that arises from the result of the analysis, also, indicates the significant and very strong influence of the brand on customer loyalty. Based on the overall results of the analysis, i.e. the stated statements, the conclusion is that the brand of the product (the reputation of the producer of 
sunflower oil), is the key driver of creating long-term value for customers. Prices are important factors in securing current customer satisfaction, but in the long run, customers are primarily focused on those supply chains with sunflower oil products that have a strong brand. These conclusions confirm $\mathrm{H} 1$ outlined at the beginning of the work: "The prices are an important factor in providing immediate customer satisfaction and loyalty, but in the long run, the brand of products or the reputation of the sunflower oil producer is the key driver of creating superior value for customers as well as longterm profit." The information obtained in this way enables the sunflower oil producer to determine the contribution that his activities aimed at increasing the satisfaction of customers have on increasing the value of the enterprise itself. In this way, H2 is also confirmed that "the input for creating the output of sunflower oil products comes from customers, i.e. from the interaction with the customers." For these companies, it is characteristic that the value-creation process is not set on the basis of the traditional formula where it begins with the input and the output is terminated (Komnenic and Lukić, 2010). In this way, changes in key customer relationship management strategies can be undertaken, such as allocation of resources and service levels, price formation, brand product, which are all in the function of increasing overall, and in particular, the financial performance of sunflower oil producer in Serbia.

From the point of view of the value of this study, it is particularly important that the results of the research confirm that in order to achieve sustainable competitive advantages, the emphasis has been put on the importance of non-financial measures of business success. In concrete researches, customer satisfaction is important and it is measured through the price and brand variables. Therefore, the modern market conditions of business imply the need to prepare financial statements for different interest groups by providing additional information in relation to those that can be read from the existing basic financial statements. "The importance of various intangible assets initiates the need to enable the presentation of those items of assets that contribute to the value of the enterprise which, according to the existing IFRS (International Financial Reporting Standards), do not meet the requirements for disclosing in the balance sheet (Šaponja and Gravorac, 2014)".

\section{Literature}

1. Gummesson, E. (2008), Total Relationship Marketing, Elsevier, Amsterdam, pp. 5-6.

2. Gupta, S., Lehmann, D. (2006a), Managing Customers a Investments, Pearson Education, New Jersey, pp. 154-155.

3. Kotler, P. (2000), Marketing Management, Millenium ed., Prentice-Hall, Upper Sadlle, River, NJ, p. 34.

4. Gupta, S., Lehmann, D. (2006a), Managing Customers a Investments, Pearson Education, New Jersey, стр. 154-155.

5. Kaplan, R.S. and Norton, D.P. (1992), The Balanced Scorecard-Measures That 
Drive Performance, Harvard Business Review, January-February, 71-79.

6. Lukić, R., Nikolić, D. (2009), Vrednovanje kupčevog kapitala, časopis, Hotel-link, br. 13-14, sstr. 943, Visoka hotelijerska škola, Beograd.

7. Woodruff, R.B. (1997).Customer value: the next source for competitive advantage, Journal of the Academy of Marketing Science, Vol. 25, No. 2, pp. 139-53.

8. Marinković, R. V. (2012), Marketinški aspekti satisfakcije i lojalnosti: orijentacija na potrošače u savremenom bankarskom poslovanju, Ekonomski fakultet, Kragujevac, str. 189-241.

9. Kumar, V. (2006a), CLV: The Databased Approach, Journal of Relationship Marketing, Best Business Books, New York, vol. 5, стр. 9.

10. Gupta, S., Lehmann, D. (2006), Customer Lifetime Value and Firm Value, Journal of Relationship Marketing, vol. 5, pp. 87-110, Best Business Books, New York.

11. Kaplan, R. S. and Norton, D. P. (1992), The Balanced Scorecard - Measures that Drive Performance, Harvard Business Review, Vol. 70, No 1, pp. 71-79.

12. Wu, C. R., Lin, T. C., Tsai, H. P. (2009), Analyzing alternatives in financial services for wealth management banks: the analytic network process and the balanced scorecard approach, IMA Journal of Management Mathematic, Oxford Journals, Volume 20, стр. 303-321.

13. Kaplan, R. S. and Norton, D. P. (1996), The Balanced Scorecard - Translating Strategy into Action, Harvard Business School Press, Boston

14. Kaplan, R. S. and Norton, D. P. (2003), The Strategy Maps, Harvard Business School Press, Boston

15. Kaplan, R. S. and Norton, D. P. (2004), The Strategy Focused Organization, Harvard Business School, Press, Boston

16. Djuričin, D., Janošević S., Kaličanin Dj. (2010), Menadžment i strategija, V izmenjeno i dopunjeno izdanje, CID Ekonomskog fakulteta, Beograd, str 81-87

17. Domanović, M. V. (2010), Balanced Scorecard - Mogućnosti i efekti primene, Ekonomski Fakultet, Kragujevac, str. 20.

18. Ivkov, D. (2014), Oblikovanje finansijskih izveštaja u funkciji analize performansi poslovanja trgovinskih preduzeća, Doktorska disertacija, Ekonomski fakultet, Subotica..

19. Ivkov, D., Andjelković, S.(2013), Analaiza poslovnih performani korporacija, Univerzitet „Union - Nikola Tesla“, Beograd, str. 39, 243.

20. Lovreta, S. (1998), Trgovinski menadžment, Univerzitet u Beogradu, Ekonomski fakultet, Beograd, str. 190-192.

21. Wang, H., Hong, W (2006), „Managing customer profitability in a competitive market by continuous data mining“, Industrial Marketing Management, Vol 35, Amsterdam, pp. 715-723 
22. Gupta, S., Lehmann, D. (2006b), Customer Lifetime Value and Firm Value, Journal of Relationship Marketing, vol. 5, pp. 87-110, Best Business Books, New York.

23. Askary, S. (2013), Marketing Cost in Accounting Measurements, Accounting \& Marketing, Account Mark, Volume 2, Issue 2, April.

24. Hughes, A. (2006), Strategic Database Marketing, McGraw-Hill, New York, pp. 14.

25. Kumar, V. (2006/b), D. [2006], Customer Lifetime Value and Firm Value, Journal of Relationship Marketing, vol. 5, pp. 87-110, Best Business Books, New York, pp. 93.

26. Heskett, J., Sasser, E., Schlesinger, L. [2003], The value profit chain, The free press, New York, str. Xviii

27. Maričić, B. (2011). Ponašanje potrošača [Consumer Behavior]. Belgrade: CID.

28. Oliver, R., Rust, R., Varki, S. (1997), Customer Delight: Foundations, Findings and Managerial Insight, Journal of Retailing, vol. 73(3), pp. 18, pp. 311-320, Elsevier, Amsterdam.

29. Szwarc, P. (2005), Researching customer satisfaction \& loyalty, Kogan Page, London, str. 6-9.

30. Auh, S., Johnson, M. (2005), Compatibility effects in evaluations of satisfaction and loyalty, Journal of Economic Psychology, vol. 26, pp. 35-57, str. 36-38 i 4143.

31. Milisavljević, M.(2006), Strategijski marketing, Ekonomski fakultet, Beograd , str. 19-20.

32. Sheth, J. N., Mittal, B., Newman, B. I. (1999), Customer Behavior - Consumer Behavior and Beyond, The Dryden Press, pp. 485.

33. Payne, A., Holt, S (2001), Diagnosing customer value: integrating the valure process and relationship marketing, British Journal of Management, Vol. 12, No.2, pp. 159-182.

34. Ladhari, R., Brun, I. and Morales, M. (2008), Determinants of dining satisfaction and post dining Behavioral intentions, International Journal of Hospitality Manegement, Vol. 27, No.4, pp. 563-573.

35. Brady, M. K. and Robertson, CJ. (2001), Searching for a consensus on the antecedent role of service quality and saisfaction: an exploratory cross-national study, Journal of Business Research, Vol. 51 No.1, pp. 53-60.

36. Yang, H.E., Wu, C.C. and Wang, L.C. (2008), An empirical analysis of online game service satistaction and loyalilty, Expert Systems with Application, Vol. 22 No.1, pp.83-98. 
37. Bei, I. and Chiao, Y. (2001), An integrated model for the effects of perceived product, perceived service quality, and perceived price fairness on consumer satisfaction and loyality, Jorunal of Consumer Satisfaction, Dissatisfaktion and Complaning Behavior, Vol. 14, pp. 125-140.

38. Churchill, G., Iacobucci, D. (2002), Marketing Research, South-Western, Mason, str. 56.

39. Anđelković, S. (2001), Ponašanje potrošača u marketing istraživanjima, Beogradska poslovna škola, SIRIUS, Beograd, str. 168-170; 370-379.

40. Jeng, S. P. (2011), The effect of corporate reputations on customer perceptions and cross-buying intentions, The Service Industries Journal, 31(6), стр. 851-862.

41. Chen, P.-T., \& Hu, H.-H. (2010). The effects of relational benefits on perceived value in relation to customer loyalty: An empirical study in the Australian coffee outlets industry, International Journal of Hospitality Management, Vol. 29, pp. 405-412.

42. Johnson M, Gustafsson A, Andreassen T, Lervik L, Cha J. (2001), The evolution and future of national customer satisfaction index models. Journal of Economic Psychology 22(2), стр. 217-245.

43. Iglesias, M.., Guillén, J (2004), Perceived quality and price: their impact on the satisfaction of restaurant customers, International Journal of Contemporary Hospitality Management, Vol. 16 Iss: 6, pp.373 - 379.

44. Cronin, J. Joseph, Michael K. Brady and Tomas G. Hult. 2000. Assessing the effects of quality, value, and customer satisfaction on consumer behavioral intentions in service environments. Journal of Retailing 76 (2): 193-218.

45. Fornell C, Johnson M, Anderson W, Cha J, \& Bryant BE. (1996). The American customer satisfaction index: nature,purpose and findings. Journal of Marketing 60(4): 7-18.

46. Gaur, S.S., Xu, Y., Quazi, A., Nandi, S. (2011), Relational impact of service providers' interaction behavior in Healthcare, Managing Service Quality, 21(1), стр. 67-87.

47. Komnenić, B., Lukić, R. (2010), Karakteristike preduzeća usmerenih ka stvaranju superiorne vrednsoti za kupce i ostale stejkholdere, Škola bisznisa, br. 1, str. 53.

48. Šaponja Dmitrović, LJ., Gravorac, S. (2014), Računovodstveni informacioni sistem kao izvor konkurentske prednosti poslovnog subjekta, Anali Ekonomskog fakulteta u Subotici, Vol. 5o, broj 31, str. 365 - 384. 


\title{
UTICAJ MARKETING ODNOSA SA KUPCIMA NA FINANSIJSKE PERFORMANSE PROIZVODJAČA SUNCOKRETOVOG ULJA U SRBIJI
}

\author{
Danijela Andjelković5, Milan Vujić, ${ }^{6}$, Ana Liberakos ${ }^{7}$, Danijela Zubac ${ }^{8}$
}

\section{Sažetak}

Cilj ove studije je da se empirijskim istraživanjima utvrdi prema konceptu marketing odnosa, kako ključni atributi cene $i$ brenda kao determinante satisfakcije i lojalnosti kupaca utiču na stvaranje vrednosti za kupaca $i$ dugoročnog profita u sektoru proizvodjača suncokretovog ulja u Srbiji.

Za potrebe ove studije kreiran je upitnik kao sredstvo za prikupljanje primarnih podataka. Upitnik je struktuiran prema konstacijama koje su opredeljivale ključne atribute satisfakcije kupaca, i distribuiran na 125 ispitanaka. Korišćena je deskriptivna statistika i višestruki regresoni model analize kako bi se odredili ključni faktori atributa satisfakcije kupaca koji utiču na percipranu vrendost kupaca. Na ovaj način posmatra se uticaj satisfakcije i njenih atributa kao nefinansijskih merila na finansijska merila performansi preduzeća.

Na osnovu dobijenih rezultata, ova studija je utvrdila da faktori ključnih atributra koji se odnose na cenu i brend imaju statistički značajan uticaj na satisfakciju, pri čemu najjači uticaj ima brend proizvodjača. Rezultati istraživanja lojalnosti kupaca, kao druge ključne odrednice marketing odnosa, potvrđuju da jedino brend ima značajan $i$ veoma jak uticaj na lojalnost kupaca. Cena predstavlja važan faktor u obezbeđivanju trenutne satisfakcije kupaca, ali dugoročno gledano, kupci su prvenstveno fokusirani ka onim proizvođačima ulja koji imaju snažan brend, odnosno korporativnu reputaciju.

Studija otvara mogućnost diskusije u postojećoj literaturi tako što otkriva kako ključni atributi satisfakcije i lojalnosti kupaca utiču na stvaranje superiorene vrednosti za kupaca i dugoročne vrednosti samog preduzeća. U ovoj studiji je potvrđeno da se proces stvaranja vrednosti za preduzeće ne postavlja na osnovu tradicionalne formule gde on počinje inputom i završava se autputem. Input za stvaranje autputa preduzeća, dolazi iz interakcije sa kupcima. U tom konekstu se posmatra ekonomski efekat

5 Dr Danijela Andjelković, Docent, Univerzitet Union „Nikola Tesla“, Beograd, Fakultet za preduzetnički biznis i menadžment nekretnina, Cara Dušana br. 62-64, 11080 Beograd, Srbija, tel.: +38164222 15 61, E-mail: andjelkodani@gmail.com

6 Milan Vujić, M.A., Asistent, Visoka škola strukovnih studija- Arandjelovac, Srbija, tel.: +381 6984490 03, E-mail: kikiv91@gmail.com

7 Ana Liberakos, Asistent, Univerzitet Union „Nikola Tesla“, Beograd, Cara Dušana br. 62-64, 11080 Beograd, Srbija, Fakulte za poslovne studije i pravo, Beograd, Mladenovac, Ontario, N2T 1W3, Kanada, E-mail: ana.liberakos@gmail.com

8 Dr Danijela Zubac, Profesor strukovnih studija, Visoka tehnička škola strukovnih studija, Zvečan, E-mail: danijela.marjanovic@gmail.com 
između doslednog proizvođenja superiorne vrednosti za kupca i dugoročnog profita. Takođe, vrednost ove studije proizilazi iz rezultta istraživanja, da savremeni tržišni uslovi poslovanja nameću potrebu oblikovanja finansijskih izveštaja prema različitim interesnim grupama obezbeđujući dodatne nefinansijske mere uspešnosti i informacije u odnosu na one koje se mogu pročitati iz postojećih osnovnih finansijskih izveštaja.

Ključne reči: suncokretovo ulje, cena, brend, marketing odnosa, satisfakcija, finansijske performanse. 